\title{
REVITALIZACIJA HRVATSKOG UZGOJA MANGULICE
}

\author{
M. Čačić, Vesna Orehovački, Ž. Mahnet, V. Klišanić, \\ M. Tretinjak, Nađa Lubina Malus
}

\begin{abstract}
Sažetak
Pasmina svinja mangulica je stara pasmina svinja koja je imala veliku ulogu u hrvatskom stočarstvu u kojem se uzgaja više od stoljeće i pol, a u pojedinim razdobljima bila je najznačajnija pasmina svinja u Hrvatskoj, posebice u Slavoniji. Njezin značaj bio je velik u podmirenju prehrambenih potreba, ali i kao temelja nastanka hrvatske izvorna pasmine crna slavonska svinja. Danas se Hrvatskoj uzgaja mali broj jedinki ove pasmine, te u cilju očuvanja Hrvatska poljoprivredna agencija 2016. godine je započela postupak utemeljenja registra pasmine te $u$ izradu programa očuvanja. Registar pasmine danas broji 113 rasplodnih grla nerasta i krmača, a zastupljena su sva tri tipa mangulice (bijeli, crveni i lasasti). Iako mangulica nije naša izvorna pasmina, duga tradicija uzgoja, njezin povijesni značaj u životu građana te uloga u stvaranju crne slavonske svinje, nesumnjivo su činjenice za ulaganje intenzivnog rada u očuvanju hrvatskog uzgoja mangulice te njezino svrstavanje u Popis izvorni i zaštićenih pasmina domaćih životinja Republike Hrvatske, a što potvrđuju brojni povijesni pisani dokazi i znanstvena istraživanja.
\end{abstract}

Ključne riječi: mangulica, revitalizacija, utemeljenje registra, očuvanje, Hrvatska

\section{Uvod}

Tijekom proteklih godina uočeno je postojanje i kontinuirano povećanje grla pasmine svinja mangulica koja se povijesno uzgajala na cijelom području Republike Hrvatske, posebice $u$ istočnom kontinentalnom dijelu (Slavonija), i to sva tri tipa: bijeli, crveni i lasasti. Obzirom da povijesni zapisi i znanstvena istraživanja ukazuju na veliki tradicijski i genetski značaj pasmine mangulica za hrvatsko svinjogojstvo, stoga je od velikog značaj uz naše izvorne pasmine crna slavonska i turopoljska svinja, očuvati i preostali dio populacije mangulice kao jedinstvenog genoma. Povijesni podaci ukazuju da se uzgoj mangulice na hrvatskom tlu razvijao više od jednog i pol stoljeća, te da je ista pasmina osim uloge izvora hrane imala veliki značaj kao temelj stvaranja hrvatske izvorne pasmine crna slavonska svinja. Hrvatska poljoprivredna agencija u suradnji s uzgajivačima mangulice utemeljila je registar pasmine u 2016. godini koji trenutno broji 113 rasplodnih grla (11 nerasta i 102 krmače) u kojem su zastupljena sva tri tipa. Osnovano je krovno uzgojno udruženje u cilju kvalitetnijeg uzgojno selekcijskog rada i očuvanja pasmine. Povijesni podaci o uzgoju pasmine mangulica ukazuju ne njezin veliki značaj u hrvatskom svinjogojstvu te je neupitno ulaganje stručnog rada u očuvanje preostalog dijela populacije i svrstavanje pasmine u popis Izvornih $\mathrm{i}$ zaštićenih pasmina domaćih životinja Republike Hrvatske.

Dr. sc. Mato Čačić, Vesna Orehovački, struč.spec.ing.agr., Željko Mahnet, dipl. ing., Vedran Klišanić, dipl.ing., Mario Tretinjak, dipl.ing., Nađa Lubina Malus, dipl.ing., Hrvatska poljoprivredna agencija, Ilica 101, 10000 Zagreb.

Dopisni autor/Corresponding author: Mato Čačić; e-mail: mcacic@inet.hr 


\section{Povijest pasmine}

Mangulica je tipična masna pasmina svinja nastala u Karpatskom,,bazenu“ tijekom 19. stoljeća (Szabo i sur., 2009). U prošlosti je bila najraširenija pasmina masnih svinja, a često su je zvali "mangalica", "mongolica" i slično, no ispravan naziv je mangulica (Ilančić, 1964). Mangulica je nastala na bazi pasmine svinja "šumadinka" koju su Mađari tijekom 19. stoljeća uveliko uvozili iz Srbije. Sistematski je pasmina mangulica stvorena na imanju Kis-Jenö u Mađarskoj. Na imanje Kis-Jenö koje je bilo u vlasništvu nadvojvode Josipa, prva grla šumadinke dolaze 1830. godine kao poklon kneza Miloša Obrenovića iz Šumadije. Na imanju Kis-Jenö su šumadinke uzgajane u poboljšanim uvjetima hranidbe i držanja u čistoj krvi, a selekcija je postavljena u smjeru bijelo - sive boje dlake, dobre tovnosti i dobrog iskorištavanja krme, te je tako stvoren temelj nove pasmine nazvane mangulica. Zbog dobrih svojstava mangulica je bila jako tražena te je u zemaljskom uzgoju dijelom križana s domaćim mađarskim pasminama (bakonjskom, salontajskom i dr.), no, ipak je ostala dominantna kovrčavost dlake i dobra tovnost. Iz Mađarske se mangulica raširila po svim okolnim područjima u kojima je bila razvijena proizvodnja kukuruza, tj. u području Podunavlja, tako da se uzgajala u Mađarskoj, svim republikama bivše Jugoslavije, Bugarskoj i Rumunjskoj. Utovljene mangulice bile su prije II. Svjetskog rata vrlo tražene u Beču, Pragu i drugim okolnim državama. Nakon II. Svjetskog rata tržište za sve pasmine masnih svinja pa tako i mangulice, značajno je smanjeno, te je i broj grla mangulice značajno smanjen, a zadržavaju se u manjem broju samo u uzgoju kod privatnih uzgajivača.

\section{Opis pasmine}

Mangulica je srednje velika svinja, razmjerno kratka i široka, što osobito dolazi do izražaja kod veće kondicije grla te $\mathrm{u}$ tovu, te je vrlo otporna na bolesti i ima veliku sposobnost adaptacije na skromne uvjete držanja i hranidbe (Ilančić, 1964). Glava je srednje duga, a profilna linija nosnog dijela lubanje malo konkavna. Uši su različite, najčešće poluklopave, a ima i grla s dugim i klopavim ušima. Vrat srednje dug i mišićav, leđa su u srednje duga i blago zaobljene linije, sapi spuštene ali ne prestrme. Visina do grebena u prosjeku $70 \mathrm{~cm} \mathrm{u} \mathrm{krmača,} \mathrm{a}$ u nerasta $80 \mathrm{~cm}$. Grudi su oble i duboke. Noge pravilne, ali s ponešto nježnijim kosturom, obujma cjevanice oko $16 \mathrm{~cm}$ u potpuno razvijenih grla što ukazuje na dobru tovnost, no, iako je kostur finiji kosti su jako teške. Gubica, sise, tjelesni otvori i papci su tamnije pigmentirani. Težina krmača od $120-180 \mathrm{~kg}$, a nerasta $180-200 \mathrm{~kg}$. No, razlike u težini postoje ovisno i od tipa, s time da su bijeli i crveni tip nešto većeg okvira i težine, dok je lasasti tip najmanji i odrasle krmače su teške $100-150 \mathrm{~kg}$.

Prema boji razlikuju se tri tipa: bijeli, crveni i lasasti tip mangulice (Szabó i sur., 2009):

Bijela mangulica ima boje čekinje u rasponu od sive do žute pa čak i do žuto crvene boje, sa žućkastim i crvenkastim promjenama koje se povezuju s uvjetima držanja i vrstom tla (foto 1$)$.

Crvena mangulica ima čekinje tamnije ili svjetlije crvenkasto - smeđe boje (foto 2). Crveni tip je najmlađi, a nastao je križanjem bijele mangulice sa „szalontai“ i „ujszalontai“ mađarskim svinjama (Ujszalonta je naselje u mađarskoj županiji Békés).

Lasasta mangulica ima čekinje crne boje, dok je donji dio tijela crn ili srebreno siv, a ta svjetlija linija proteže se od usta do između do korijena repa, dok je rep bijeli s crnim 
vrhom (foto 3). Ovaj tip je nastao križanjem mangulice i "srijemske" svinje u okolici mjesta Buđanovci (Banat - Vojvodina).

Na donjem dijelu uha imaju svjetliju oznaku promjera $3-5 \mathrm{~cm}$ koja ukazuje na postupni prijelaz pigmentirane kože, a ova oznaka naziva se "Welmanovom točkom" koja je specifična za pasminu mangulica. Bez obzira na tip, čekinje su tvrde i kovrčave, zimi čvrste kao strugotine, a ljeti kraće i više glatke. Čekinje nalik na strugotine i prstenasto kovrčave čekinje te grube ravne čekinje na hrbtu i duž leđa su također specifičnost pasmine, iako su nepoželjne, kao ni previše fina vunasta čekinja. Pojava crnih čekinja i dlaka na ušima u bijele mangulice trag su stranih pasmina koje su sudjelovale u izgradnji pasmine. Oči su smeđe, a obrve i trepavice crne kod svih tipova.

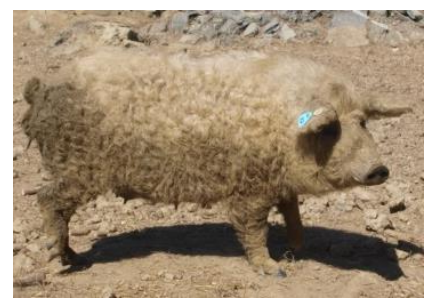

Foto 1. Bijela mangulica Photo 1 White mangulica

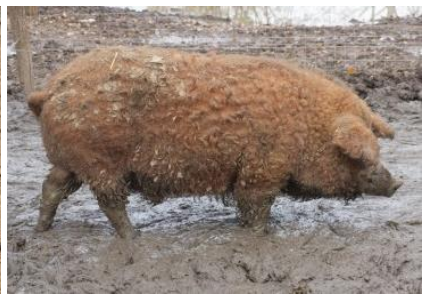

Foto 2. Crvena mangulica Photo 2 Red mangulica

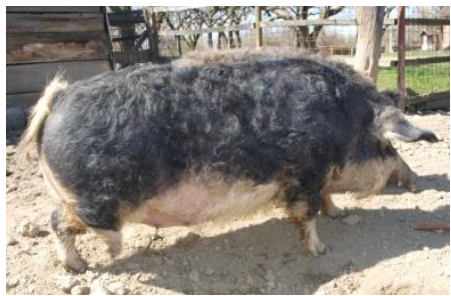

Foto 3. Lasasta mangulica Photo 3 Swallow belly mangulica

Mangulica je kasno zrela pasmina, ima sporiji rast i ulazi u rasplod tek s 12 mjeseci starosti, ali se često pripušta i ranije što uzrokuje zaostajanje u razvoju. Krmače imaju u prosjeku 10 sisa, 5 sa svake strane vimena. Krmače prase u prosjeku 5 - 6 prasadi u leglu, dok je plodnost lasaste mangulice nešto slabija (3-6 prasadi). Prasad nakon rođenja je teška oko 1,4 kg i ima uzdužne pruge tamnije i svjetlije dlake po tijelu (livreje) (foto 4).

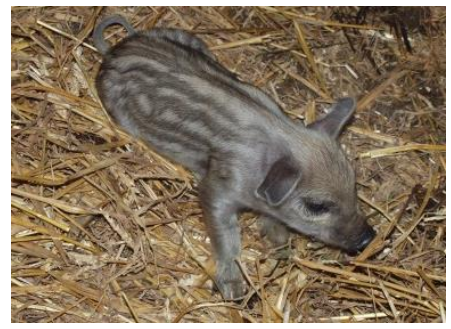

Foto 4. Livreje (pruge) na tijelu sisajuće prasadi mangulice (arhiva autora)

Photo 4 Liveries (strips) on the body of suckling pigs of Mangulica (the archive of the author)

\section{Povijest hrvatskog uzgoja}

$\mathrm{Na}$ početku 20. stoljeća mangulica je bila najznačajnija pasmina svinja na prostoru Slavonije, Vojvodine, sjeverne Srbije i Bosanske Posavine (Izvješće o radu zemaljske gospodarstvene uprave Kraljevine Hrvatske i Slavonije 1896. - 1906., 1907; dalje u tekstu i: Izvješće 1896. - 1906.). Prije toga vremena mjesto najznačajnije pasmine svinja zauzimala je 
pasmina "šiška" koju je mangulica zbog boljih proizvodnih svojstava potpuno istisnula. Na prostoru Slavonije mangulica se počela najprije uzgajati na prostoru od Virovitice do Koprivnice (utjecaj Mađarske), a vrlo brzo uzgoj se proširio na sve krajeve u kojima je bilo velikih površina pod hrastovim i bukovim šumama te prostranih pašnjaka, obzirom da se svojim karakteristikama skromnosti i otpornosti mangulica u istim uvjetima držanja mogla vrlo dobro uzgajati. Upravo radi skromnosti i otpornosti mangulica se mogla uzgajati u svim krajevima te se uzgoj brzo širio i u plemenitaška i u mala seljača imanja.

Najkvalitetniji uzgoji mangulice prema Izvješću 1896. - 1906. bili su uzgoji grofa Majlatha u Donjem Miholjcu, grofa Jankovića u Cabuni, grofa Pejacsevicha u Našicama, vlastelina Leopolda pl. Pfeiffera u Orlovnjaku (foto 5), Vase Maučevića u Osijeku te grofa Eltza u Vukovaru.

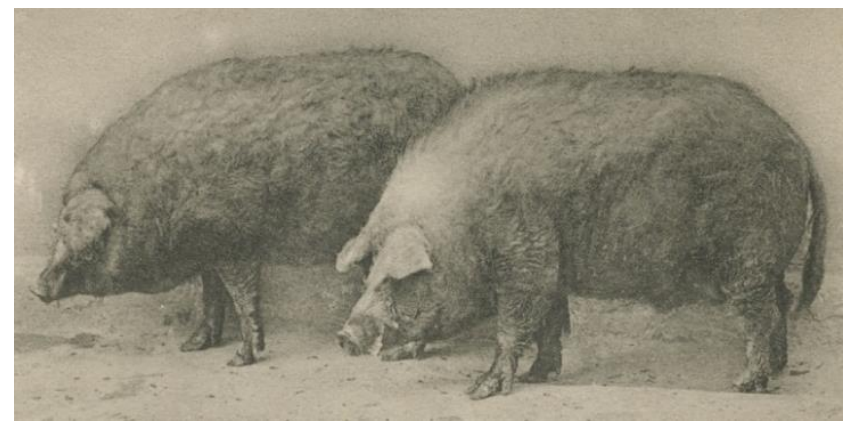

Foto 5. Nerast i krmača bijele mangulice na vlastelinstvu u Orlovnjaku (Izvješće o radu zemaljske gospodarstvene uprave Kraljevine Hrvatske i Slavonije 1896.-1906., 1907)

Photo 5 Boar and sow of White mangulica on the farm in Orlovnjak (Report on the Work of the Territorial Economy of the Kingdom of Croatia and Slavonia 1896-1906, 1907)

U cilju genetskog unaprjeđenja navedenih uzgoja dopremana su izravno rasplodna grla iz poznatih po kvaliteti uzgoja u Kis-Jenö, Pankoti i Mezöhegyesu. No, kako bi se cjelokupan uzgoj na prostoru Hrvatske unaprijedio, Zemaljska vlada Kraljevine i Slavonije je 1901. godine utemeljila $u$ Kraljevskoj ratarnici u Požegi malu farmu mangulice $u$ tipu reprodukcijskog centra s 2 nerasta i 6 nazimica dopremljenih iz Šumadije, a u svrhu rasploda kasnije su dopremani i nerasti iz uzgoja Kis-Jenö, Donjeg Miholjca i Cabune. Godine 1906. uzgoj u Požegi je brojio 9 nerasta i 40 krmača, no to je bilo premalo matično stado kako bi se zadovoljio interes za nabavkom čistokrvnih mangulica u svrhu rasploda od strane privatnih uzgajivača. Prepreka za povećanje matičnog stada u Kraljevskoj ratarnici u Požegi je nedostatak poljoprivrednih površina za proizvodnju krme. Iz toga razloga Kraljevska ratarnica u Požegi i u idućim godinama i dalje kupuje grla iz Kis-Jenö, Donjeg Miholjca i Cabune, te ih dijelom uvodi u uzgoj, a dijelom prodaje privatnim uzgajivačima u cilju oplemenjivanja populacija domaćih svinja.

Savez selekcijskih zadruga za uzgoj svinja u svom Izvještaju o radu i bilanci za poslovnu godinu 1934. iznosi podatak da je pod selekcijski obuhvat u zadružnom uzgoju u 1934. godini odabrano, ocijenjeno, označeno i upisano u matične knjige ukupno 208 grla bijele mangulice 
(tablica 1), a ista godina smatra se godinom organiziranog selekcijskog rada na ovoj pasmini. U istom aktu (Izvještaj za 1934.) dani su privremeni selekcijski standardi za bijelu mangulicu.

Tablica 1. Broj grla bijele mangulice pod obuhvatom saveza selekcijskih zadruga za uzgoj svinja 1934. godine

Table 1 Number of white mangulica covered by alliance of cooperative for selection in 1934 .

\begin{tabular}{lcccc}
\hline Zadruga & Nerasti & Krmače & Muški pomladak & Ženski pomladak \\
\hline Čepin - Knobloch E. & 2 & 8 & 19 & 45 \\
Čepin - Knobloch O. & 3 & 10 & 58 & 52 \\
Ernestinovo - Reiner R. & 1 & 10 & - & - \\
\hline Ukupno & 6 & 28 & 77 & 97 \\
\hline
\end{tabular}

Krajem prve polovice 20. stoljeća jedan od najkvalitetnijih uzgoja bijele mangulice bio je uzgoj Dobra Biskupije Đakovo koji je razvijan za podmirenje prehrambenih potreba svećenstva, a dio grla prodavan je za oplemenjivanje domaćih svinja na području Đakovštine (foto 6 i 7). Uzgoj Dobra Biskupije Đakovo osnovan je domaćim mangulicama koje se prema zapisu Ilančić i Romić iz 1940. godine na vlastelinstvu uzgajaju već 70 godina. U vlastelinstvo Dobra Biskupije Đakovo 1934. godine dopremljena su 3 nerasta iz Niže gospodarske škole u Požegi i jedan nerast iz imanja Lederer u Čoki (Vojvodina - Sjeverni Banat). Na ženskim potomcima u dobi od 14 mjeseci ovih nerasta Ilančić i Romić (1940) provode jedno od prvih opsežnijih istraživanja tjelesnih mjera bijele mangulice. Dodatno, u istraživanje uključuju i krmače malih seoskih imanja u mjestima Vrpolje, Viškovci, Semeljci, Budrovci i drugim. Ilančić i Romić (1942) i Romić (1965) u razdoblju od 1934. do 1954. godine provode istraživanje klaoničke vrijednosti bijele mangulice, također na području Đakova. Navedena istraživanja potvrda su razvijenosti uzgoja bijele mangulice u okolici Đakova kao posljedica utjecaja vlastelinstva Dobra Biskupije Đakovo na svinjogojstvo đakovštine, ali i dokaz o postojanju razvijenog hrvatskog uzgoja mangulice.

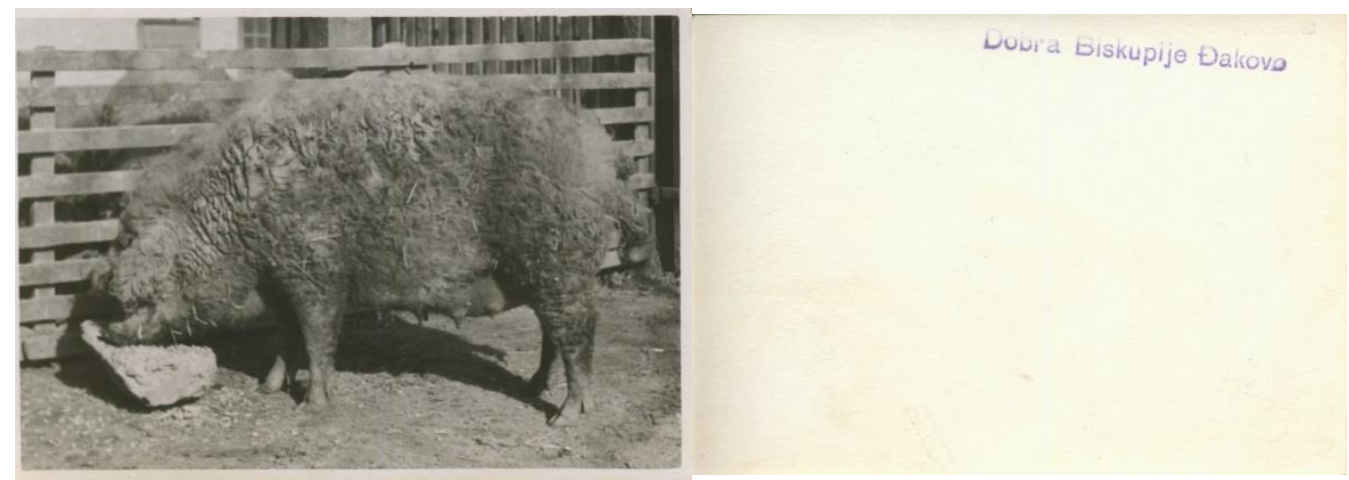

Foto 6. Krmača bijele mangulice na imanju Dobra Biskupije Đakovo 1940. (na poleđini fotografije istaknut je originalni pečat Dobra Biskupije Đakovo; arhiva autora)

Photo 6 Sow of White mangulica at the Bishopric Đakovo Property in 1940 (original seal of Bishopric Đakovo Property on the back of the photo) 

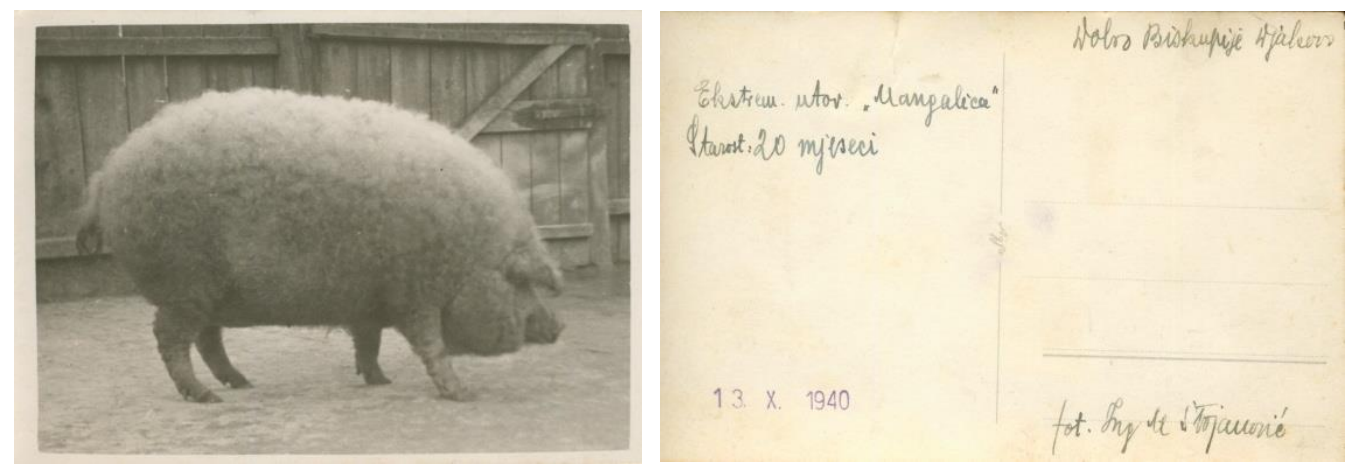

Foto 7. Tovljenik bijele mangulice na imanju Dobra Biskupije Đakovo 1940. (na poleđini je istaknuto mjesto i datum fotografiranja te kategorija i autor fotografije; arhiva autora) Photo 7 The fatling pig of White mangulica at the Bishopric Đakovo Property in 1940 (place and date of the photo, pig category and author are on the back of the photo)

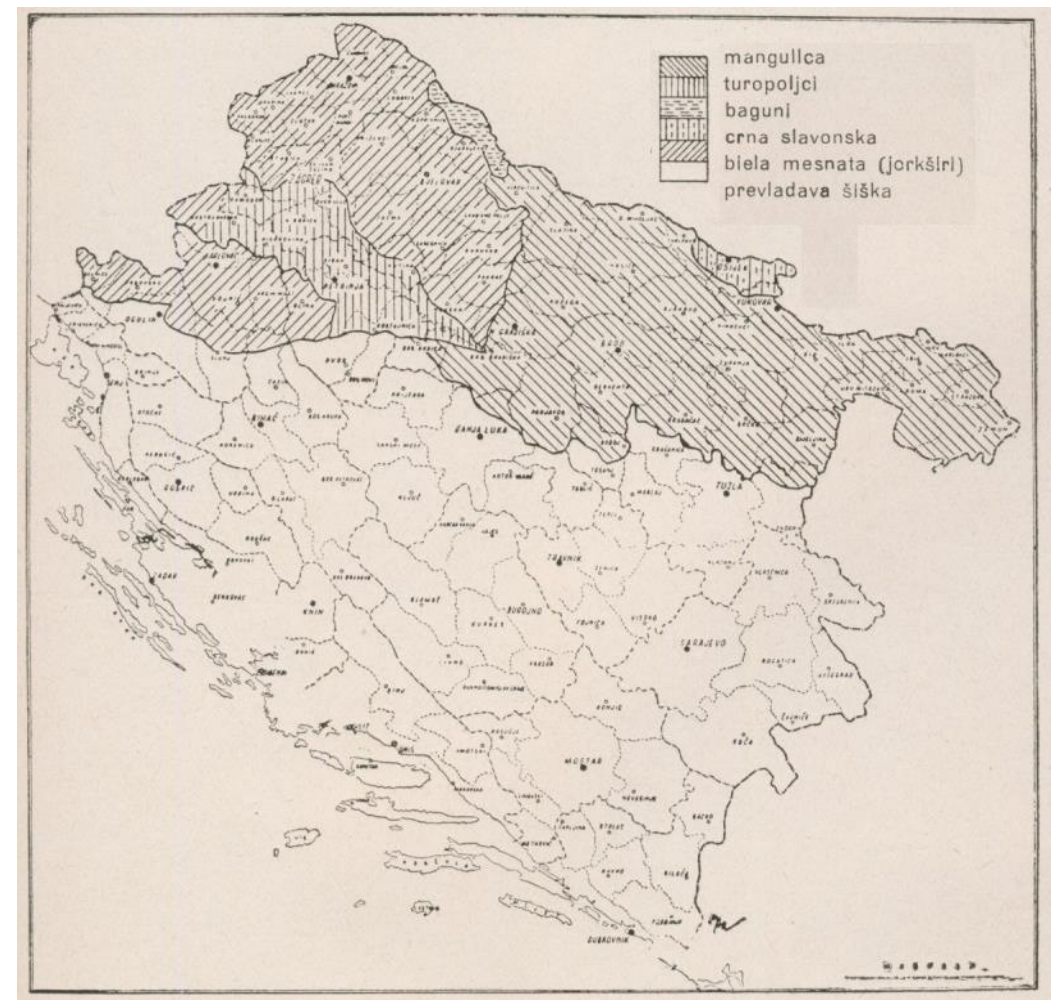

Prikaz 1. Pasminska struktura uzgoja svinja 1942. godine u Hrvatskoj (Pavlinić, 1944) Figure 1 Breed structure of pig breeding in Croatia in 1942. (Pavlinić, 1944) 
Prema podacima o stanju stočarske proizvodnje 1942. godine u vrijeme Nezavisne Države Hrvatske, nacionalna svinjogojska proizvodnja podijeljena je u dvije glavne skupine, na svinje za proizvodnju masti i svinje za proizvodnju mesa (Pavlinić, 1944). U skupini svinja za proizvodnju masti ubrajaju se domaće pasmine mangulica, turopoljska svinja i bagun koje su činile čak 43\% ukupne populacije svinja. U drugoj skupini svinja od $20 \%$ za proizvodnju čini najvećim dijelom pasmina jorkšir te manjim dijelom berkšir. Preostali dio nacionalne populacije svinja od 36\% čini pasmina šiška i brojni razni križanci, dok crna slavonska svinja ima udio tek oko $1 \%$. U isto vrijeme izražen je na nacionalnoj razini planski proces oplemenjivanja domaćih pasmina s pasminama jorkšir, njemačkom oplemenjenom svinjom, lincoln i drugim plemenitim pasminama te se u tom razdoblju često moglo vidjeti razne križance plemenitih s domaćim pasminama svinja. Najveća rasprostranjenost pasmine mangulica bila je na prostoru istočnog dijela Hrvatske (prikaz 1).

Pasmina svinja mangulica osim što je sama bila u prošlosti značajna za prehranu stanovništva, imala je veliku ulogu u povijesti hrvatskog svinjogojstva obzirom da je bila temelj stvaranja crne slavonske svinje kao izvorne hrvatske pasmine. Početak stvaranja crne slavonske svinje ili kako je još nazivaju "fajferica" ili "Pfeifferova svinja", započinje 1860. godine kada je na svom vlastelinstvu Karl Pfeiffer započeo program križanja berkšir nerasta s 10 krmača lasaste mangulice u cilju poboljšanja kvalitete mesa mangulice, ali uz zadržavanje njenih dobrih tovnih osobina (Ilančić, 1964).

\section{Utemeljenje pasminskog registra 2016. godine}

Nakon provedenog višekratnog terenskog rada sveukupno je označeno 113 grla mangulice, prema tipu 69 grla bijele mangulice, 18 grla crvene i 26 grla lasaste mangulice (tablica 2), a ista grla ažurirana su kao početna populacija jedinki kojima je utemeljen registar. Obzirom da je prvi terenski rad označavanja proveden 3.11.2016. godine, možemo reći da je 2016. godina u kojoj je postupkom revitalizacije utemeljen pasminski registar.

U sva tri tipa uočava se nerazmjer između broja muških i ženskih rasplodnih jedinki (nerasta i krmača), a najnepovoljniji omjer spolova je aktualnoj populaciji crvenog tipa.

Stručna procjena učinjena tijekom terenskog rada označavanja prvih rasplodnih jedinki svinja pasmine mangulica, je da je ukupna populacija kada se uzme u obzir zatečeni pomladak, trostruko veća od označenih grla rasplodne populacije. Označavanje i ažuriranje u pasminski registar rasplodnog dijela populacije omogućava da se u pri označavanju aktualnog i budućeg pomlatka istom evidentira roditeljsko porijeklo. Sastavni dio daljnjeg terenskog rada činiti će i aktivnost prikupljanja vjerodostojnih podataka o veličini populacije i njenim proizvodnim osobinama.

Registar pasmine je još uvijek „otvoren“ sve dok se ne provede cjelokupan terenski rad označavanja postojećih rasplodnih grla pasmine mangulica. Nakon završetka označavanja i upisa $\mathrm{u}$ registar pasmine svih dojavljenih rasplodnih grla, registar pasmine će se voditi $\mathrm{u}$ obliku ,zatvorene“ matične knjige, odnosno isključivo u čistoj krvi (bez uvođenja grla drugih pasmina) i bez uvođenja u uzgoj grla u tipu mangulice nepoznatog porijekla. 
Tablica 2. Struktura pasminskog registra mangulice od utemeljenja do danas Table 2 Structure of the breed registry of mangulica from founding till now

\begin{tabular}{|c|c|c|c|c|c|c|c|c|c|}
\hline \multirow{2}{*}{\multicolumn{2}{|c|}{ Uzgajivač }} & \multirow{3}{*}{ Mjesto } & \multirow{3}{*}{$\begin{array}{l}\text { Datum prvog } \\
\text { označavanja }\end{array}$} & \multicolumn{6}{|c|}{ Tipovi mangulice } \\
\hline & & & & \multicolumn{2}{|c|}{ Bijela } & \multicolumn{2}{|c|}{ Crvena } & \multicolumn{2}{|c|}{ Lasasti } \\
\hline Ime & Prezime & & & $\hat{0}$ & 우 & $\hat{O}$ & 오 & $\hat{0}$ & 오 \\
\hline Željko & Grigić & Lovas & 03.11 .2016 & 1 & 2 & - & - & - & - \\
\hline Josip & Krivić & Ladimirevci & 10.11.2016. & 3 & 31 & - & 6 & - & 3 \\
\hline Franjo & Kovačević & Budrovci & 10.11.2016. & 1 & 2 & - & - & - & - \\
\hline Vladimir & Ivanac & Jasenaš & 22.11.2016. & 1 & 3 & - & - & - & 3 \\
\hline Terezija & Škrinjarić & Pivare & 01.03.2017. & 1 & 6 & - & - & - & - \\
\hline Barica & Boić & Banovci & 01.03.2017. & - & 1 & - & - & - & - \\
\hline Željko & Grigić & Lovas & 10.03.2017. & - & - & - & - & 1 & 4 \\
\hline \multirow[t]{4}{*}{ Damir } & Šarac & Rogoža & 28.03.2017. & - & 17 & 1 & 11 & 2 & 13 \\
\hline & & \multicolumn{2}{|c|}{ Ukupno prema spolu: } & 7 & 62 & & 17 & 3 & 23 \\
\hline & & \multirow{2}{*}{\multicolumn{2}{|c|}{$\begin{array}{l}\text { Ukupno prema tipu (\%): } \\
\text { Omjer spolova prema tipu: }\end{array}$}} & \multicolumn{2}{|c|}{$69(61 \%)$} & \multicolumn{2}{|c|}{$18(16 \%)$} & \multicolumn{2}{|c|}{$26(23 \%)$} \\
\hline & & & & & 89,9 & & 4,4 & 11, & 88,5 \\
\hline
\end{tabular}

\section{Sistematizacija pasminskog registra}

Vjerodostojna matična evidencija omogućava plansko vođenje uzgoja (planske pripuste) u cilju očuvanja i povećanja genetske varijabilnosti te izbjegavanja štetnih utjecaja uzgoja u srodstvu (inbreedinga). Selekcijski odgovor u zatvorenom uzgoju je povećanje koeficijenta inbreedinga koji rezultira smanjenjem genetske varijabilnosti za daljnju selekciju, što može uzrokovati inbreeding depresiju fitness svojstava. Ovu činjenicu treba imati na umu prilikom dizajniranja uzgojnog programa. Uzgojni ciljevi i ekonomski čimbenici mogu značajno utjecati na razinu inbreedinga u nekoj konačnoj populaciji. Genetska varijabilnost je čimbenik koji značajno utječe na uspješnost selekcije koja se smanjuje u populaciji pod selekcijskim obuhvatom. Vjerodostojan rodovnik pasmine osnova je svakog modernog konzervacijskog programa i kontrolirane zaštite izvornih pasmina domaćih životinja.

U cilju postavljanja planskog vođenja uzgoja u cilju očuvanja genetske varijabilnosti unutar pasmine, slijedeći korak u radu na pasminskom registru je provedba sistematizacije cjelokupnog uzgoja, odnosno definiranje linija muških (nerasta) i rodova ženskih (krmača) grla. Definiranje linija nerasta i rodova krmača osnovni je preduvjet za izradu plana pripusta za sva rasplodna grla. Definiranjem linija nerasta i rodova krmača moguće je planski izbjegavati nepoželjan uzgoj u srodstvu, odnosno pojavu inbreeding depresija. U slučaju mangulice čija populacija je brojno mala, to je vrlo značajno. Potreba za uspostavljanjem linija i rodova te izradom precizne sheme sparivanja zabilježena je i u mnogim hrvatskim izvornim pasminama domaćih životinja.

Vjerodostojno vođenje rodovničke evidencije pasmine temeljni je čimbenik u uzgoju i očuvanju izvornih pasmina domaćih životinja. Informativan i vjerodostojan rodovnik čini osnovu svakog modernog konzervacijskog programa. Zbog nepostojanja planskog i ravnomjernog pripusta svih linija nerasta i rodova krmača te kontrole izlučivanja iz uzgoja (klanja), postoji veliki rizik od gubljenja dijela izvorne genetske varijabilnosti. Slučaj gubljenja genetske varijabilnosti zapažen je u više izvornih pasmina domaćih životinja. 
Sistematizacija početnog uzgoja mangulice, tj. definiranje linija nerasta i rodova krmača provedena je naznačavanjem oznake tipa i rednog broja linije nerasta, odnosno roda krmača, a koji će biti ažurirani u matičnoj evidenciji pasmine te će iste oznake biti istaknute i na rodovniku svake jedinke. Oznake tipa naznačene su slovima: B - bijela mangulica, C - crvena mangulica i L - lasasta mangulica. Linije nerasta definirane su slovnim oznakama B, C ili L, dok su rodovi prema tipu označeni s dvije slovne oznake: BM, CM i LM, pri čemu slovna oznaka M ima značenje "mangulica". Oznake rednog broja linije nerasta i roda krmača naznačene su rednim brojem prema redoslijedu terenskog označavanja $(1, \ldots)$. Za istaknuti je da sistematizacija i dalje traje, tako da se broj linija i rodova u narednom vremenu može povećavati sve do „zatvaranja“ matične knjige pasmine.

Sukladno navedenom, u dosadašnjem radu na utemeljenju registra mangulice sistematizirano je 11 linija nerasta i 102 roda krmača i to prema tipu:

- Bijele mangulica: 7 linija $(B 1, \ldots$, B7) i 62 roda krmača $(B M 1, \ldots$, BM62)

- Crvena mangulica: 1 linija (C1) i 17 rodova krmača (CM1, .., C17)

- Lasasta mangulica: 3 linije (L1, L2, L3) i 23 roda krmača (LM1, ..., LM23)

\section{Efektivna veličina populacije}

Efektivna veličina populacije $\left(N_{e}\right)$ pasmine mangulica utvrđena prema metodologiji Falconera (1989) $\left[N_{e}=4 \times\left(N_{m} \times N_{f} / N_{m} \times N_{f}\right) N m\right.$ - broj rasplodnih muških jedinki, $N f$-broj rasplodnih ženskih jedinki] koja je međunarodno prihvaćena (FAO) u monitoringu izvornih i zaštićenih pasmina domaćih i populacija divljih životinja, a koja se temelji na ravnoteži i broju muških i ženskih rasplodnih jedinki u populaciji, aktualna populacija pasmine svinja mangulica ima vrijednost $N_{e}=39,37$. Prema vrijednosti $N_{e}$ aktualna hrvatska populacija može se kategorizirati kao IA, odnosno kritično ugrožena.

Obzirom da aktualnu populaciju čine tri tipa i da se u cilju proizvodnje uzgojno valjanih grla moraju sparivati muške i ženske jedinke istog tipa, tj. nije dozvoljeno sparivanje nerasta i krmača različitih tipova nužno je utvrditi $N_{e}$ unutar svakog tipa. Sukladno broju nerasta i krmača istog tipa u aktualnoj populaciji, najugroženiji je crveni tip $\left(N_{e}=3,78\right)$, manje ugrožen je lasasti $\left(N_{e}=10,62\right)$ i najmanje bijeli tip $\left.N_{e}=25,16\right)$ mangulice.

\section{Pohrana biološkog materijala u banku gena}

Prilikom terenskog rada označavanja prvih rasplodnih jedinki (nerasta i krmača) aktualne populacije mangulice, svakom grlu uzet je biološki materijal (tkivo kivetom i dlaka) radi pohrane u Banku animalnih gena domaćih životinja Republike Hrvatske. Svrha uzimanja biološkog materijala je dvostruka. Jedan razlog je pohrana u banku gena, a drugi je u svrhu genetskog tipiziranja svake jedinke početne populacije pasmine mangulica kojima je utemeljen pasminski registar. Genetsko tipiziranje omogućiti će vjerodostojnu izgradnju rodovnika pasmine, kao vjerodostojno plansko vođenje uzgoja temeljeno na genetskoj strukturi svake jedinke. Pohrana biološkog materijala svake označene jedinke i pohrana u banku gena nastaviti će se kontinuirano provoditi i u budućnosti. 


\section{Osnivanje krovnog uzgojnog udruženja}

Nedugo nakon početka terenskog rada označavanja i ažuriranja prvih rasplodnih grla pasmine svinja mangulica kao osnivača pasminskog registra, zajedničkom inicijativom Odjela za Središnju banku animalnih gena i Odjela za svinjogojstvo Hrvatske poljoprivredne agencije, potaknuto je osnivanje krovnog pasminskog udruženja. Krovno uzgojno udruženje temeljni je preduvjet uspješne provedbe selekcijskog rada i ostvarivanja zajedničkih interesa uzgajivača, a sve to u cilju uspješnijeg razvoja i očuvanja mangulice. Udrugu je osnovalo osam uzgajivača pasmine svinja mangulica (tablica 3).

Tablica 3. Osnivači udruge uzgajivača svinja pasmine mangulica

Table 3 Founders of mangulica pig breeders association

\begin{tabular}{c|l|l|l}
\hline $\begin{array}{c}\text { Redni } \\
\text { broj }\end{array}$ & Ime i prezime & Mjesto & Županija \\
\hline 1. & Željko Grigić (predsjednik) & Trnava & Osječko - baranjska \\
2. & Josip Krivić (zamjenik predsjednika) & Ladimirevci & Osječko - baranjska \\
3. & Mirjana Škrinjarić (tajnica) & Pivare & Brodsko - posavska \\
4. & Mladen Škrinjarić & Pivare & Brodsko - posavska \\
5. & Vladimir Ivanac & Virovitica & Virovitičko - podravska \\
6. & Luka Ivanac & Virovitica & Virovitičko - podravska \\
7. & Ivan Kovačević & Budrovci & Osječko - baranjska \\
8. & Mato Boić & Bebrina & Brodsko - posavska \\
\hline
\end{tabular}

Dana 12. listopada 2016. godine u Đakovu održana je Osnivačka skupština na kojoj je osnovana "Udruga uzgajivača svinja pasmine mangulica", a skraćeni naziv udruženja glasi "Udruga mangulica". Naziv udruge na engleskom jeziku glasi "Mangulica Pig Breeders Association", a skraćeni naziv "Association of Mangulica". Sjedište udruge je na adresi Vladimira Nazora 1, 31400 Đakovo. Glavni ciljevi rada Udruge su: unaprjeđenje znanja i vještina uzgajivača, ustrojavanje uzgojnog programa, povećanje broja uzgajivača, brojno povećanje pasmine, unaprjeđenje proizvodnih svojstava pasmine, povećanje proizvodnje i prerade, te razvoj tržišta pasmine i proizvoda od istih.

\section{Izrada i verifikacija uzgojnog programa}

Nakon provedene pravne registracije Udruge uzgajivača pasmine svinja mangulica, slijedi izrada zajedničkog uzgojnog programa sva tri tipa mangulice kojim će se definirati svi postupci uzgojno - selekcijskog rada u cilju kako očuvanja pasmine tako i genetskom unaprjeđenju i stvaranju uvjeta za postizanje dohodovnosti pasmine kroz različite vidove korištenja, ponajprije u proizvodnji tradicijskih prehrambenih proizvoda.

Nakon izrade i usvajanja uzgojnog programa od strane Skupštine Udruge, uzgojni program treba biti upućen u Ministarstvo poljoprivrede Republike Hrvatske u cilju njegove verifikacije, nakon koje udruga može biti upisana u Registar uzgojnih udruženja Republike Hrvatske kojeg vodi resorno ministarstvo. 


\section{Zaključak}

Pasmina svinja mangulica nije izvorna pasmina svinja, no ima vrlo dugu tradiciju uzgoja na prostoru Republike Hrvatske, a što potvrđuju brojni povijesni zapisi kao i objavljena znanstvena istraživanja. Osim što je pasmina u povijesti bila značajna kao sredstvo podmirenja prehrambenih potreba, pasmina mangulica je bila temelj stvaranja izvorne pasmine crna slavonska svinja, što dodatno ukazuje na dugu povijest uzgoja i njezin značaj za hrvatsko svinjogojstvo u prošlosti i danas.

Krajem 2016. godine započeo je intenzivan rad na utemeljenju registra pasmine mangulica te je do sada odabrano, označeno i u pasminski registar ažurirano sveukupno 113 rasplodnih nerasta i krmača sva tri tipa (bijeli, crveni i lasasti). Usporedo s utemeljenjem registra provodi se sistematizacija uzgoja, odnosno definiraju se linije nerasta i rodovi krmača u svrhu stvaranja uvjeta za plansko vođenje uzgoja i dizajniranja dugoročnog i kvalitetnog programa konzervacije. Registar pasmine za sada je još uvijek „otvoren“. Prilikom terenskog rada odabira i označavanja prvih rasplodnih jedinki zamijećeno je da u matičnim stadima pojedinih uzgajivača nalazimo grla križance tri tipa mangulice kao posljedicu da matična stada čine dva pa i sva tri tipa koja se drže i rasplođuju međusobno. Od presudnog je značaja kako bi se sva tri tipa očuvala i proizvodila uzgojno valjana grla ove pasmine u rasplodu sparivati isključivo neraste i krmače istog tipa. Jedinke koje su rezultat križanja različitih tipova nisu uzgojno valjana grla i neće moći biti ažurirana u pasminski registar.

Nakon pravne registracije Udruge uzgajivača pasmine svinja mangulica, slijedi izrada uzgojnog programa i njegova verifikacija u Ministarstvu poljoprivrede Republike Hrvatske, čime će udruženje dobiti status uzgojne organizacije kao samostalne u uzgojnom radu, obzirom da će ista biti nosioc odobrenog uzgojnog programa. Slijedeći korak je izrada marketing plana za proizvedene tradicijske suhomesnate proizvode od pasmine svinja mangulica kao put ka povećanju dohodovnosti i očuvanju pasmine.

Pasmina mangulica u hrvatskoj regulativi neupitno se ubraja u kategoriju Izvornih i zaštićenih pasmina Republike Hrvatske, no ne u skupinu izvornih nego u skupinu zaštićenih pasmina zbog duge tradicije uzgoja i povijesnog značaja. U istu skupinu ubraja se i lipicanska pasmina konja koja također nema izvorno ishodište u Republici Hrvatskoj, ali je hrvatski uzgoj u povijesti imao veliku ulogu u izgradnji cjelokupne pasmine i današnje aktualne populacije lipicanskih konja, a posljedično je pasmina imala veliki značaj u životu hrvatskih građana. Zaključno, slučaj pasmine mangulica potpuno je identičan.

\section{LITERATURA}

1. Čačić, M., V. Orehovački (2017.): Utemeljenje pasminskih registara u Banka gena domaćih životinja Republike Hrvatske - Godišnje izvješće za 2016. godinu. Hrvatska poljoprivredna agencija. Zagreb

2. Falconer, D.S. (1989.): Introduction to Quantitative Genetics, Ed. 3. Longmans Green/John Wiley \& Sons, Harlow, Essex, UK/New York

3. Ilančić, D. (1964.): Svinjarstvo, u Specijalno stočarstvo. Zavod za izdavanje udžbenika Socijalističke Republike Srbije. Beograd. Str. $229-339$. 
4. Ilančić, D., S. Romić (1940.): Prilog poznavanju tjelesnih mjera bijele mangulice. Veterinarski arhiv, 10 (5): $225-253$.

5. Ilančić, D., S. Romić (1942.): O klaoničkoj vrijednosti bijele mangulice. Veterinarski arhiv, 12 (1)

6. Pavlinić, P. (1944.): Stočarstvo Nezavisne Države Hrvatske u 1942. Ministarstvo Narodne prosvjete - Glavno ravnateljstvo za promičbu. Zagreb

7. Romić, S. (1965.): Klaonička vrijednost bijele mangulice u različitoj dobi. Poljoprivredno znanstvena smotra, 20 (2): $23-45$.

8. Szabó, P., L. Kürti, P. Tóth (2009.): The breeding programme for mangalica pig breeds. Hungarian National Association of Mangalica Breeders. Debrecen, 15th April 2009.; http://www.mangalicatenyesztok.hu/tenyesztesi_program-english.html, 28.11.2015.

9. * Izvješće o radu Zemaljske gospodarske uprave Kraljevine Hrvatske i Slavonije god. 1896. 1905., sa dodatkom za godine 1906. i 1907. Svezak III. Gojidba domaće živine i veterinarstvo. Naklada Kraljevine Hrvatsko - Slavonsko - Dalmatinske Zemaljske vlade. Zagreb, 1907.

10. ** Izvještaj o radu i bilanca za poslovnu godinu 1934., te zapisnik III. redovite godišnje Glavne skupštine Saveza selekcijskih zadruga za uzgoj svinja k.s.z. u Zagrebu, 1934.

11. *** Hrvatska poljoprivredna agencija (2017): Podaci Jedinstvenog registra domaćih životinja Republike Hrvatske

\section{REVITALIZATION OF CROATIAN BREEDING OF MANGULICA}

\section{Summary}

Mangulica pig breed is an old pig breed that has played a major role in Croatian cattle breeding for more than a century and a half, and in some periods was the most important pig breed in Croatia, especially in Slavonia. Her significance was great in meeting nutritional needs, but also as the basis for creation of the Croatian autochthonous pig breed - black Slavonian pigs. Today, a small number of pigs of this breed is reared in Croatia, and in order to preserve it, in 2016, the Croatian Agricultural Agency started the process of founding the breed register and preparation of the conservation program. The breed register today counts 113 breeding sows and boars, and all three types of Mangulica are represented (white, red and red). Although Mangulica is not our original breed, the long tradition of rearing, its historical significance in the lives of people, and the role in the creation of black Slavonian pigs, are undoubtedly the facts for investing in intensive work in preservation of Croatian breeding of Mangulica and its classification in the List of native and protected breeds of domestic animals of the Republic of Croatia, which is confirmed by numerous historical written evidence and scientific research.

Key words: mangulica, revitalization, establishment of the register, preservation, Croatia

Primljeno - Received: 08.05.2017.

Prihvaćeno - Accepted: 13.02.2018. 